\title{
The Cambridge BEC as an Academic Context Model of Problematic Situations in Professional Intercultural Communication
}

\author{
Olga A. Marina and Olga V. Smirnova* \\ National Research University \\ Higher School of Economics \\ 20 Myasnitskaya Str., Moscow, 101000, Russia
}

Received 04.11.2015, received in revised form 17.02.2016, accepted 28.02.2016

The article aims at finding appropriate measurement instruments for the assessment of communication mobility (CM) development as an important component of professional intercultural communicative competence. The comparative analysis of the BEC speaking exam paper and communication mobility strategies and tactics shows that the exam format covers the components of CM model to a large extent and consequently may be used to measure the level of communication mobility development in the absence of a specifically designed instrument. Moreover, the analysis suggests teaching implications that entail addressing the issues of non-linguistic strategies and tactics explicitly at the exam preparation stage as well as in ESP teaching in general.

Keywords: professional intercultural communicative competence, measuring communication mobility, communication strategies and tactics, BEC speaking exam, teaching English for specific purposes (ESP).

DOI: 10.17516/1997-1370-2016-9-4-953-959.

Research area: sociology, culture studies.

\section{Introduction}

Due to the expansion and development of cross-cultural contact, the importance of learning a foreign language for specific purposes has increased. The introduction of the third generation of Federal State Higher Education standards has entailed changes both to the level and quality of education, and tightened the requirements for professionally oriented foreign language acquisition. The necessity of foreign language skills for professional purposes has been noted by Russian and foreign studies (Kankaanranta, 2010; Krupchenko, 2013). This need is also confirmed by a HSE graduate survey conducted in 2013 and involving 96 participants HSE graduates of 2007-2012 (Marina, 2014). Most respondents $(78 \%)$ reported that a good knowledge of a foreign language (English in this case) had played a crucial role in their employment. Moreover, $64.5 \%$ of the respondents are still striving to improve their English language skills to pursue their career goals (such

(C) Siberian Federal University. All rights reserved

* Corresponding author E-mail address: marinaolga2008@yandex.ru 
as promotion opportunities). Another pragmatic purpose of English teaching is preparation for international exams, which are essential for academic and professional mobility. At present the format of these exams (predominantly IELTS and BEC) is reflected in the curricula of a number of non-linguistic universities, e.g. the Higher School of Economics, Moscow. Half of the survey respondents received an international exam certificate after graduation having passed these exams independently.

Compared with interpersonal monocultural communication, communication in an intercultural environment seems to be more complex, especially in the professional sphere. The intercultural professional context, with its linguistic and non-linguistic peculiarities, can increase the risk of misunderstanding between the interlocutors which may result in serious professional problems like the termination of contracts or termination of business relations (often with financial consequences).

\section{Theoretical framework}

According to the research on professional intercultural communication, its components may be grouped into four sections (Marina, 2014) - the structural components of communicative competence; the individual factors influencing the personalized character of communicative performance, and the nature of the communication context, and communication mobility (Smirnova 2013; Marina \& Smirnova, 2013).

The nature of communicative language ability (CLA) involves not only knowledge or competence in the language concerned, but also the capacity to implement this competence (Widdowson, 1983). Bachman (1990), and later Bachman and Palmer (2010) have suggested that CLA consisted of three components: language competence, strategic competence, and the psychophysiological mechanisms involved in the actual execution of language. Douglas (2000) modified Bachman's model of language for specific purposes by adding the notion of background knowledge. Furthermore, the conceptual framework for professional communicative competence was defined to specify the expected outcome in the workplace for experimental sciences. Ezeiza (2009) developed the general configuration of the domain-specific communicative framework, consisting of ten variables: communication context, communication aim, discourse subject, focus, communication mode, audience, media and support, process and operations involved, communicative language activities, and text types. The major components of this framework for domain-specific communication include personal and social skills, instrumental skills, functional skills, special discourse-writing knowledge, knowledge of the criteria behind academic and professional styles, and specific lexical-semantic knowledge (Marina \& Rajprasit, 2014).

Communicative competence is seen as a complex phenomenon which involves linguistic and non-linguistic factors including the ability to effectively apply communicative skills in various situations. A remarkable feature of professional communication situations is their problematicity, which requires special communicative abilities, which may be regarded as communication flexibility. To overcome communication problems researchers suggest using specific problem-solving communication strategies.

According to the Communication Strategies (CSs) Taxonomy (Dörnyei \& Scott, 1995a, 1995b), the manner of addressing communication problems (i.e. resource deficit, processing time pressure, own-performance problems, and otherperformance problems) falls into three basic 
strategies: direct, indirect and interactional strategies.

\section{Communication Strategies \\ (Dörnyei \& Scott, 1995a, 1995b)}

1. Direct strategies (meaning-related):

- resource deficit-related strategies,

- own-performance problem-related strategies,

- other-performance problem-related strategies.

2. Indirect strategies (problem-managingrelated):

- processing time pressure-related strategies,

- own-performance problem-related strategies,

- other-performance problem-related strategies.

3. Interactional strategies (cooperativerelated):

- resource deficit-related strategies,

- own-performance problem-related strategies,

- other-performance problem-related strategies.

Thus, direct strategies are used as alternative, manageable, and self-contained means of getting one's meaning across. Indirect strategies convey the meaning indirectly by creating the conditions and indicating lessthan-perfect forms for mutual understanding, preventing breakdowns, or keeping the communication channel open. Interactional strategies are aimed at cooperative troubleshooting exchanges from a communication partner.

However, recently with the introduction of a new term - Communication Mobility (CM), another outlook on communication strategy has been suggested. The idea of CM is reflected in its problem-solving nature. $\mathrm{CM}$ is aimed at enabling communicators, particularly non-native speakers of English, to achieve their communicative goal in an international professional context (Marina \& Smirnova, 2013; Smirnova, 2013).

CM refers to the ability to solve communicative problems in different communicative encounters through the use of particular strategies and tactics. Among the suggested strategies are: diagnostic strategy, schema search strategy, observation strategy, individual active strategy, interactive strategy, implementation strategy, and analytical strategy). Each strategy consists of tactics which individually support communicators in an effective communicative approach.

\section{Communication Mobility \\ (Marina \& Smirnova, 2013)}

1. Diagnostic strategy:

- Identifying and assessing a communicative situation.

2. Schema search strategy:

- Reactivating communication experience (professional, interpersonal, intercultural) in a new environment.

3. Observation strategy:

- Gaining problem solving experience from observing instances of problem solving in communicative situations.

4. Individual active strategy:

- Searching for a solution to a problem by obtaining information from a communication partner/s.

5. Interactive strategy:

- Finding a solution to the problem by working with a partner or partners of communication.

6. Implementation strategy:

- Implementing a devised solution.

7. Analytical strategy:

- Analyzing the effectiveness of an applied solution. 
Both CSs and CM are similar in terms of providing speakers with effective devices to handle communication problems in communicative situations and events in which the English language is used as a medium. Moreover, they tend to benefit all non-native speakers who intend to reach the communicative goal in both academic and professional arenas.

Comparative analysis of CSs and CM has shown that the main difference between these phenomena lies in the fact that CSs are predominantly linguistically oriented or compensatory for linguistic deficiency whereas $\mathrm{CM}$ strives for a comprehensive framework of strategies which enable the user to be a successful communicator in uncertain situations. Still, there has been no in-depth research conducted on any of the factors that may influence the development of communication mobility, or further exploration of the issue of its teachability (Marina, Rajprasit, 2014) and means of measuring it.

\section{Method}

The article discusses possible ways to gauge the level of communication mobility development. For this purpose it seems logical that the BEC Higher exam format may be suggested as a proper instrument for measuring the level of communication mobility development.

Thus, we undertake an analysis of the BEC speaking paper format with the purpose of defining the communication mobility strategies and tactics employed by examinees during their examination performance.

\section{The structure of the oral BEC exam part. PART 1 - INTERVIEW}

This part tests the candidates' ability to respond to questions and expand on responses.

For this part of the test, the interlocutor asks the candidates questions on a number of personal or work-related subjects.

\section{PART 2 - LONG TURN}

This part tests the candidates' ability to sustain a 'long turn'.

In this part, each candidate's task is to choose one topic from a set of three, and to talk about it for one minute. Candidates have one minute in which to prepare, and should use this time to make brief notes. While one candidate speaks, the other listens, and then asks a question at the end of the talk.

Candidates may make notes while listening to their partner. Each candidate is given a different set of three tasks from which to choose.

The candidates are advised to structure the one-minute talk, with an introduction and conclusion (however brief these must necessarily be), and to make the structure explicit when giving the talk, in order to show some evidence of planning.

Candidates should approach the task as if giving a presentation in a business environment.

Examples of topic areas include: advertising, career planning, communications, customer relations, finance, health and safety, management (personnel, production, transport, etc.), marketing, recruitment, sales, technology, training and travel.

\section{PART 3 - COLLABORATIVE TASK}

This part tests the candidates' ability to communicate with one another, negotiate, initiate, and respond in an appropriate way.

This is a two-way collaborative task based on a prompt which is given to both candidates. The prompt consists of several sentences presenting a business-related situation followed by two discussion points. Candidates are given time to read the prompt and then discuss the situation together.

Candidates need to approach the task as a simulation, imagining themselves in a work 
environment, faced with a real situation to discuss, and on which they should try to reach decisions. The opinions they express, however, will be their own, as they are not required (as in some kind play) to assume particular attitudes or opinions.

As we see, the format covers all components of CM model (general and professional language skills, cognitive skills and cultural awareness) which manifest themselves throughout problematic situations of professional intercultural communication.

It should be noted that observing time constraints is an essential strategy required throughout the exam as it is an essential part of the exam format.

\section{Discussion}

The undertaken analysis has brought up some expected results: as an exam of professional English language ability by design it covers all linguistic aspects of communicative competence. An interesting finding is that though BEC claims to test and measure linguistic competence, it also requires quite a number of non-linguistic strategies, such as orienting to the context, observing time constraints, interactive skills etc. Still in exam preparation the issues of non-linguistic strategies and tactics are rarely addressed on their own and taught explicitly.

While it is highly noticeable that almost all aspects of the exam format correlate with $\mathrm{CM}$ strategies and tactics to a large extent, the analytical strategy is an exception. It seems to be a point that may suggest important teaching implications. As it is not a part of the exam, it may never get a development boost if left unattended. Students, who do not possess developed self-analytical skills, may not give a thought to whatever communication breakdowns they have experienced while performing in the exam and allow these covert weaknesses to remain unaddressed. This leads to the danger for

Table 1. Below shows which strategies and tactics of CM are required to perform successfully in the different parts of the BEC exam

\begin{tabular}{|c|c|}
\hline $\begin{array}{l}\text { Communication Mobility } \\
\text { (Marina \& Smirnova, 2013) }\end{array}$ & Employed in the parts of BEC \\
\hline $\begin{array}{l}\text { Diagnostic: } \\
\text { Identifying and assessing } \\
\text { a communicative situation }\end{array}$ & $\begin{array}{l}\text { Parts } 1-3 \text { (but especially Part } 1 \\
\text { while orienting to the examination environment) }\end{array}$ \\
\hline $\begin{array}{l}\text { Schema search: } \\
\text { Reactivating communication experience (professional, } \\
\text { interpersonal, intercultural) } \\
\text { in a new environment }\end{array}$ & $\begin{array}{l}\text { Parts 1-3 (but especially pronounced in Part } 2 \\
\text { while choosing one of the topics and Part } 3 \text { when } \\
\text { making sense of the prompt) }\end{array}$ \\
\hline $\begin{array}{l}\text { Observation strategy: } \\
\text { Gaining problem solving experience from observing } \\
\text { instances of problem solving in communicative } \\
\text { situations }\end{array}$ & $\begin{array}{l}\text { Parts 1-2 (e.g. observing the speaking partner talk or } \\
\text { answer the examiner's questions as every candidate is } \\
\text { given a chance to be second to speak). }\end{array}$ \\
\hline $\begin{array}{l}\text { Individual active strategy: Searching for a solution } \\
\text { to a problem by obtaining information from a } \\
\text { communication partner/s }\end{array}$ & Part 3 while performing for the collaborative task. \\
\hline $\begin{array}{l}\text { Implementation strategy: } \\
\text { Implementing a devised solution }\end{array}$ & Parts 1-3 throughout the exam. \\
\hline $\begin{array}{l}\text { Analytical strategy: } \\
\text { Analyzing the effectiveness of an applied solution }\end{array}$ & - \\
\hline
\end{tabular}


students keep stumbling over the same problems again and again.

The implications for teaching may be that analytical strategy should be incorporated into class teaching for students to self-assess and reflect on their chosen communicative strategies and tactics after each oral exam practice. This strategy is an essential part of PBL which requires a full closed-loop approach for students' analytical skills development.

\section{Conclusion}

Though the undertaken preliminary analysis is limited in scope and depth, we may conclude, that in the absence of a specifically designed instrument for measuring the level of CM development, the BEC oral exam may serve as a useful tool by proxy. It is due to the fact that BEC exam communicative situations model the situations of professional intercultural communication to a considerable degree.

Still, the increasing importance of teaching for specific purposes, and particularly for professional communication require further research into both the methodology of teaching and measurement instruments design and implementation.

\section{References}

Bachman, L. (1990). Fundamental considerations in language testing. Oxford: Oxford University Press.

Bachman, L. F., \& Palmer, A. S. (2010). Language assessment in practice. Oxford: Oxford University Press.

Business English Certificates. Handbook for teachers. UCLES 2008 (www.CambridgeESOL. org)

Dornyei, Z., Scott M. L. (1997). Communication strategies in a second language: definitions and taxonomies, in Language learning, 47 (1). 173-210.

Douglas, D. (2000). Assessing languages for specific purposes. Cambridge: Cambridge University Press.

Ezeiza, J. (2009) Communicative competence in experimental sciences degrees within the framework of the new European Space for Higher Education, in Iberica, 18, 131-152.

Kankaanranta, A. (2010). BELF competence as business knowledge of internationally operating business professionals, in Journal of Business Communication, 47(4), 2010, 380-407.

Krupchenko, A.K. Foundations of Professional Linguodidactics, in Professional Linguodidactics in Higher Education, 1, 2013, 10-20.

Marina, O. (2014), Approaches to teaching Speaking for Specific Purposes (SSP). Methodology of Higher School Teaching, St. Petersbourgh, Vol. 3 (17) (in print).

Marina, O. (2014), Structural components of foreign language communicative competence as a professional strategic resource. Pedagogical Education and Science (in print).

Marina, O., Rajprasit, K. (2014), Investigating the impact of personality factors on perceived communication mobility of non-native English speaking Thai professionals in international companies, in A Journal of Language Teaching and Learning in Thailand (PASAA), 47: January June, 2014.

Smirnova, O. (2013). Developing communication mobility of university students in economics. Dissertation. Kandidat Nauk. Moscow. 
Tareva, E. (2007). Personal-developing potential of a textbook in a foreign language. Educationalmethodical complex for the teaching foreign language in non-language schools: theory and practice of development. M.: Rem.

Widdowson, H. G. (1983). Learning Purpose and Language Use. London: Oxford University Press.

\title{
Устный экзамен ВЕС
}

\section{как модель проблемной коммуникативной ситуации профессионального общения}

\section{в академическом контексте}

\author{
О.А. Марина, О.В. Смирнова \\ Национальный исследовательский университет \\ «Высшая школа экономики» \\ Россия, 101000, Москва, ул. Мясниикая, 20
}

\begin{abstract}
Статья посвящена поиску подходящзих способов измерения сформированности коммуникативной мобильности - значимого компонента профессиональной межскультурной коммуникативной компетенции. $B$ качестве инструмента для измерения уровня сформированности коммуникативной мобильности предложен формат устной части экзамена BEC Higher. В результате сравнительного анализа устной части данного экзамена и стратегий и тактик коммуникативной мобильности выявлено, что формат экзамена ВЕС Higher совпадает почти со всеми компонентами модели коммуникативной мобильности, проявляюшейся в проблемных профессиональных ситуациях межкультурной коммуникации. Установлено, что аналитическая стратегия не отражена в формате экзамена, но она может быть использована для развития аналитических умений, самооченки и самоконтроля.
\end{abstract}

Ключевые слова: профессиональная межкультурная коммуникативная компетенция, измерение коммуникативной мобильности, коммуникативные стратегии и тактики, устный экзамен ВЕС, обучение английскому языку для специальных иелей.

Научная специильность: 22.00.00 - социологические науки, 24.00.00 - культурология. 